- VR can boost students' creative and critical thinking by making problem-solving decisions.

- VR can provide participant with an immediate feedback and motivate student to move on.

The above-mentioned benefits and ways of using VR technology let us assume that it should take place in education. This line of research is methodologically important for VR-based education development and experimental verification.

\title{
References:
}

1. Eichenberg, Christiane, ed. Virtual reality in psychological, medical and pedagogical applications. 2012. P. 3-35.

2. Johnson-Glenberg, Mina C. The Necessary Nine: Design Principles for Embodied VR and Active Stem Education. Learning in a Digital World. Springer, Singapore. 2019. P. 83-112.

3. Kamińska D., Sapiński T., Wiak S., Tikk T., Haamer R. E., Avots E., Anbarjafari G. Virtual reality and its applications in education: Survey. Information, № 10.2019 .20 p.

DOI https://doi.org/10.30525/978-9934-588-80-8-2.33

\section{MODERN ART PRACTICES AND METHODS OF WORKING WITH CHILDREN WITH SPECIAL EDUCATIONAL NEEDS}

\author{
Voronina H. L. \\ Candidate of Pedagogical Sciences, \\ Senior Lecturer at the Department of Human Growth and Development \\ Kharkiv Academy of Continuing Education \\ Churkina V. H. \\ Candidate of Art History, \\ Assistant Professor at the Department of Human Growth and Development \\ Kharkiv Academy of Continuing Education \\ Kharkov, Ukraine
}

The purpose of the article is to outline modern methods of working with children with special educational needs, which are artistic practices (public art).

Aesthetic principles of art pedagogy and art therapy, art practices (public art) and creative industries allow to attract the full potential of art and 
cultural and artistic education to the development of human resources necessary for the use of their valuable cultural capital [2, p. 10].

Scholars view school art education as a means of preserving cultural diversity and intercultural understanding in Europe. for The development of aesthetic taste, the acquisition of skills to evaluate works of art in art education creates conditions for the formation of general cultural competence of the individual, the perception of national culture as a source of self-identity, respect for other cultures, motivation for creativity, personal artistic views and preferences [3]. Age and place of residence, including for citizens with special needs. The influence of art on man is manifested in the reconstruction of the traumatic situation through artistic and creative activities, allows for positive changes in the psychological, physical, and even physiological states of man. It is proved that during the process of «creating masterpieces» there are positive emotions - joy, surprise, novelty, which allows you to experience certain negative moments (illness, injury, death of loved ones, etc.). And such properties of art become relevant in the organization of inclusive education.

The concept of inclusion is already entrenched in the domestic educational space and is interpreted as a process of active inclusion in the social relations of all citizens, regardless of their physical, intellectual, cultural, linguistic, national and other characteristics. The Law of Ukraine «On Education» states that a child with special educational needs is a person who needs additional permanent or temporary support in the educational process in order to preserve his right to education [4, p. 10]. An inclusive approach in art education involves the involvement of artistic practices in the process of creating «masterpieces», which arouses positive emotions: joy, surprise, novelty which allows you to experience certain negative moments (illness, injury, death of loved ones, etc.). Such properties of artistic practices are now being studied by scholars in relation to inclusion issues, as the art-therapeutic potential of art in its various aspects has recently been recognized and used as a method of socializing and adapting people who have problems interacting with others. their experience of inclusion in artistic creativity or contemplation of works of art (V. Zhiltsov, S. Larionov, O. Ustinov, etc.); as a method of psycho-corrective influence of artistic creativity on the personality (T. Zboryuk, V. Vanova, V. Odentsova, O. Stavytska); as a means of correlation-correcting influence on people with special needs due to artistic and creative activity (E. Hrabovska, E. Zinyuk, etc.).

According to I. Zvereva, the influence of art on a person is manifested in the reconstruction of a traumatic situation with the help of artistic and creative activities. The scientist defines the main directions of art therapy: isotherapy (therapeutic effect of fine arts - modeling, painting, arts and 130 
crafts; bibliotherapy (therapeutic effect of reading); imagotherapy (treatment through art, dramatization); music therapy (music therapy); (kinesitherapy (therapeutic effect of movements - choreotherapy, corrective rhythmics) [1, p. 65]. «Art therapy - a method of treatment based on the use of artistic creativity, which is co-creation, sensory dialogue, understanding. This is a characteristic feature of art and there is a philosophical basis of art therapy» [1, p. 31].

A. Zakhovaeva believes that "the effectiveness of art therapy is that art allows in a special symbolic form to reconstruct the conflict traumatic situation and find its solution...» [6, p. 31]. The influence of lines, shapes and colors (chromotherapy according to A. Zakhovaieva) has a positive effect on the inner state of man. And music therapy allows to influence positively at the cellular level through artistically decorated sounds, and at libropsychotherapy such effect is reached owing to reading of works of fiction; in theater therapy, this effect is provided by plasticity and the phenomenon of theatrical synthesis of arts.

Involvement of a person in artistic and receptive activity and artistic creativity always forms the aesthetic and artistic experience of the individual. This practice makes it possible to realize the relaxation, cathartic or compensatory (therapeutic) potential of art. It has been proven that classes in various arts allow not only to have fun, provide leisure and aesthetic pleasure, but also promotes self-affirmation, relaxation or compensation, so involvement in artistic creativity or artistic-receptive practice helps to reduce stress, anxiety, dissatisfaction with their own otherness. (the phenomenon of «art-therapeutic effect» («art-relaxation aesthetic» and "art-compensatory aesthetic») works [5, p. 20].

Foreign scientists have concluded that a number of musical works, such as the music of Wolfgang Amadeus Mozart and John Coltrane, have a positive effect on children with epilepsy. Listening to musical masterpieces and immersing yourself in the musical background dramatically reduces the frequency of epileptic seizures. This allows patients to feel the therapeutic effect of music from this incurable disease. Scientists explain this phenomenon by the fact that epileptics have much higher brain activity when listening to music than in healthy people. The brain of a child with OOP is synchronized with music, and this, in turn, prevents epileptic seizures. Thus, we can conclude that music therapy affects the human body and mind.

Thus, the use of color affects the organs and systems of the human body, because colors stimulate or inhibit their action. There are three types of color effects on humans: physical, optical and emotional. Color as energy is needed to maintain the tone of the central nervous system of a child with PLO. Swiss scientist Max Luscher argued that orange-red changes the heart 
rate, respiration, blood pressure and excites a person. Dark blue, on the contrary, soothes. Therefore, use different colors for therapeutic purposes.

Dance therapy allows you to reflect the personal characteristics of the child. Dancing is a way of communicating without words, with emotional relaxation. Creative projects and exercises are the main method of consolidating the acquired knowledge and are aimed at developing certain skills and abilities related to various types of artistic activity - art, arts and crafts, music, art and speech, theatrical. The whole system of various rhythmic exercises is developed for the purpose of development of movements under music, opening of possibilities of the child.

\section{References:}

1. Art-terapiia. Sotsialna pedahohika : mala entsyklopedisa / za zah. red. I. D. Zvierievoi. K. : Tsentr ychbovoi literatury, 2008. $336 \mathrm{s.}$

2. Dorozhnaia karta khudozhestvennogo obrazovaniia: sozdaniie tvorchesкоgo potentsiala dlia XXI veka / Vsemirnaia konferentsiia po obrazovaniiu v овлаsti iskusstv, Lissabon, 6-9 marta 2006 g. URL: http://portal.unesco.org/culture/en/files/40399/

3. Nакаz Ministerstva kultury «Pro zatverdzhennia Kontseptsii suchasnoi mystetskoi shkoly vid 20 hrudnia 2017 roku № 1433 URL: http://mincult.kmu.gov.ua/control/uk/publish/article?art_id=245415870\&cat _id $=245415844$

4. Poroshenko M.A. Inkluzyvna osvita: navch. posib. K, 2019. 300s.

5. Salenko O. P. Sinestezaiя v konteksti art-terapii: estetychnyi aspekt: dys. kand. filosof. nauk.: spetsialnst 09.00.08 - estetyka; Zhytomyrskyi derzhavnyi universytet im. Ivana Franka. Zhytomyr, 2015. 202 s.

6. Zakhovaieва A. G. Isкusstvo kak gumanizuiushchiy fenomen (sotsialno-filosofskaia traktovka) : avtoref. dis. doktora filosof. nauk : spetsialnost 09.00.11 - sotsialnaia filosofiia. Ivan. gos. med. akad. Ivanovo, 2005. 35s. 